\title{
Aksi Peduli COVID-19 Berupa Sosialisasi dan Gerakan Vaksinasi sebagai Adaptasi Merdeka Belajar Kampus Merdeka ITKES Muhammadiyah Sidrap Bersama Lawan COVID
}

\author{
St. Hasriani*1, Asmah Sukarta², Sunandar ${ }^{3}$, Rusdiana ${ }^{4}$ \\ 1,2,3,4 Pendidikan Profesi Bidan, Fakultas Keperawatan \& Kebidanan, ITKES Muhammadiyah \\ Sidrap, Indonesia \\ *e-mail: sthasrianistkm@gmail.com ${ }^{1}{ }^{2}$ asmahsukarta@gmail.com ${ }^{2}{ }_{2}$ nandaralipatada@gmail.com ${ }^{3}$, \\ rusdianaana@gmail.com ${ }^{4}$
}

\begin{abstract}
Abstrak
Pandemi COVID-19 telah menyebar dan menimbulkan dampak yang sangat signifikan pada seluruh aspek bidang aktivitas masyarakat di Indonesia yaitu ekonomi, kesehatan, sosial dan budaya. Beberapa upaya, strategi dan kebijakan telah dilakukan oleh pemerintah untuk mencegah dan mengurangi penyebaran COVID-19. Vaksinasi COVID-19 merupakan salah satu upaya pemerintah Indonesia dalam menangani masalah COVID-19 bertujuan untuk menciptakan herd immunity. Munculnya berbagai isu terkait efek samping vaksinasi sehingga banyak masyarakat yang ragu bahkan menolak melakukan vaksinasi, walaupun sudah teruji aman dan halal. Sosialisasi dan pemberian vaksinasi COVID-19 dipusatkan di ITKES Muhammadiyah Sidrap. Strategi pengabdian masyarakat ini menggunakan metode sosialisasi dan pemberian vaksinasi. Hasil pengabdian masyarakat ini memberikan kesadaran kepada masyarakat tentang tujuan vaksinasi dan peserta vaksinasi mendukung kegiatan ini dan sangat antusias untuk mendapatkan vaksinasi.
\end{abstract}

Kata kunci: COVID-19, Kampus Merdeka, Sosialisasi, Vaksinasi

The COVID-19 pandemic has spread and has had a very significant impact on all aspects of community activities in Indonesia, namely economic, health, social and cultural. Several efforts, strategies and policies have been carried out by the government to prevent and reduce the spread of COVID-19. The COVID-19 vaccination is one of the Indonesian government's efforts in dealing with the COVID-19 problem, which aims to create herd immunity. The emergence of various issues related to the side effects of vaccination so that many people are hesitant and even refuse to vaccinate, even though it has been tested to be safe and halal. The socialization and provision of COVID-19 vaccination was centered at ITKES Muhammadiyah Sidrap. This community service strategy uses the method of socialization and vaccination. The results of this community service provide awareness to the public about the purpose of vaccination and vaccination participants support this activity and are very enthusiastic about getting vaccinated.

Keywords: COVID-19, Independent Campus, Socialization, Vaccination

\section{PENDAHULUAN}

Badan Kesehatan Dunia (WHO) telah menetapkan wabah yang dihadapi yaitu COVID-19 sebagai pandemi diseluruh Negara (Hartini, Nuraeni, Hayuningtyas, \& Serli, 2020). Virus corona atau novel Coronavirus (2019-nCoV) menyebar sangat cepat ke negara-negara di dunia, dan mulai merebak akhir Desember 2019 di Kota Wuhan, Provinsi Hubei, China (Indrawati, 2020). Sejak Bulan Maret 2020 di Indonesia pandemi COVID-19 telah menyebar dan menimbulkan dampak yang sangat signifikan pada seluruh aspek bidang aktivitas masyarakat yaitu ekonomi, kesehatan, sosial dan budaya (Rachmadi, Rahayu, Waluyo, \& Yuliyanto, 2021).

COVID-19 tidak hanya berkeliaran di perkotaan, namun di pedesaan juga. Karena virus ini adalah virus bawaan dari orang yang berada di daerah kena virus. Dan virus ini tidak bisa dijangkau oleh mata, namun terasa dalam diri manusia dengan salah satu cirinya adalah bebatuk yg keras. Mungkin batuk yang seperti itu akan dianggap biasa oleh orang lain, namun, bisa jadi batuk itu adalah batuk karena virus. Meskipun saat ini virus tidak terdengar 
menakutkan seperti tahun kemarin, namun masyarakat tetap dihimbau untuk tetap waspada dan mematuhi segala protokol kesehatan demi kesehatan (Novianto, et al., 2021).

Berbagai upaya dan strategi yang telah dilakukan tidak serta merta menghentikan penyebaran COVID-19 hingga kini, oleh karena itu pembentukan herd immunity (kekebalan masal) menjadi alternatif terakhir yang dapat dilakukan untuk mencegah penularan COVID-19, namun pembentukan herd immunity secara natural dengan penularan COVID-19 yang kini terjadi tidak akan berjalan cepat dibandingkan dengan pemberian imunisasi secara masal melalui vaksinasi (Nurdiana, Marlina, \& Adityasning, 2021).

Vaksinasi COVID-19 merupakan salah satu upaya pemerintah Indonesia dalam menangani masalah COVID-19, yang bertujuan untuk menciptakan kekebalan kelompok (herd immunity) agar masyarakat menjadi lebih produktif dalam menjalankan aktivitas kesehariannya (Dewi \& Bustan, 2021). Walaupun sudah teruji aman dan halal, namun masih banyak opini masyarakat yang ragu bahkan menolak melakukan vaksinasi Isu mengenai efek samping jangka panjang yang belum terbukti, pengadaan yang terkesan terburu-buru, kesimpangsiuran informasi akan efektivitas vaksin, hingga adanya konspirasi politik ditengah pengadaan vaksin menjadi dasar adanya penolakan di masyarakat. Maka dari itu, perlu adanya sosialisasi dan edukasi massif, tepat sasaran dan dilakukan secara kontinyu mengenai pentingnya vaksinasi COVID-19, sehingga dapat meningkatkan kesadaran masyarakat dan tidak lagi menimbulkan polemik di kemudian hari (Novita1 \& Ramadhani, 2021)

Sosialisasi yang dilakukan merupakan kegiatan pengabdian masyarakat ini melibatkan mahasiswa dimana merdeka belajar - kampus merdeka sesungguhnya memberi kesempatan kepada mahasiswa untuk memperluas wawasan maupun pergaulannya untuk terjun ke dunia kerja senyatanya (Indiani, 2021). Merdeka Belajar di perguruan tinggi yang lebih otonom. Prinsipnya, perubahan paradigma pendidikan agar menjadi lebih otonom dengan kultur pembelajaran yang inovatif. Oleh karena itu pengajar bersama mahasiswa dapat melakukan bersama dan membuat suatu inovasi dalam belajar (Indrawati, 2020).

Dari kegiatan ini diharapkan dapat memutus rantai penularan Penyakit COVID-19, merubah pola perilaku masyarakat setelah diberikan vaksinasi. Selain itu, tujuan pemberian Vaksinasi COVID-19 ini adalah meningkatkan imunitas kekebalan tubuh dengan mengaktifkan antibodi dalam tubuh supaya dapat mengurangi dampak dari penularan Penyakit COVID-19.

\section{METODE}

Proses perencanaan kegiatan pemberian Vaksinasi COVID-19 dilakukan melalui pertemuan koordinasi antara Dinas Kesehatan kabupaten Sidenreng Rappang, Ketua Satuan Tugas (Satgas) COVID-19 Kabupaten Sidenreng Rappang dan Puskesmas Pangkajene serta Puskesmas Lancirang. Dalam pertemuan koordinasi ini menentukan prioritas sasaran vaksinasi COVID-19 kepada masyarakat. Pemberian Vaksinasi COVID-19 untuk sasaran masyarakat dilaksanakan pada bulan September 2021 di Kampus ITKES Muhammadiyah Sidrap Kabupaten Sidrap.

Unsur-unsur yang terlibat dalam pemberian Vaksinasi COVID-19 ini menggunakan metode strategi penyuluhan dalam memberikan sosialisasi dan informasi pemberian Vaksinasi COVID-19 kepada masyarakat. Dari hasil pemberian penyuluhan dan informasi tersebut kemudian unsur-unsur yang terlibat dalam pemberian Vaksinasi COVID-19 mendata peserta sasaran vaksinasi untuk didaftarkan pada sistem entri vaksinasi COVID-19 di Puskesmas.

Pada pelaksanaan kegiatan pengabdian kepada masyarakat dilakukan sosialisasi dan pemberian vaksinasi sebagaimana dijelaskan dalam Tabel 1.

Berdasarkan Tabel 1 tersebut dapat dijelaskan ada tiga jenis metode dalam pengabdian masyarakat pemberian vaksinasi COVID-19 yaitu perencanaan, pelaksanaan dan evaluasi. Dalam tahap perencanaan dilaksanakan pertemuan koordinasi untuk menetapkan pembagian tugas tim, menetapkan lokasi, waktu pemberian vaksinasi dan sasaran vaksinasi. Dalam perencanaan ini melibatkan unsur Satgas COVID-19 Kabupaten Sidrap, tenaga kesehatan dan lintas sektor masyarakat. Pada tahap pelaksanaan dilakukan jenis metode penyuluhan bagi peserta sasaran 
vaksinasi dan pemberian vaksinasi COVID-19. Dalam tahap ini meliputi prosedur kegiatan pemberdayaan masyarakat mengajak kelompok sasaran mengunjungi lokasi vaksinasi, memberikan penyuluhan, informasi dan sosialisasi kepada masyarakat, selanjutnya tim Vaksinasi memberikan pelayanan vaksinasi kepada masyarakat. Tahap evaluasi dilakukan analisis jumlah peserta sasaran yang divaksinasi, kasus Kejadian Ikutan Pasca imunisasi bila ada, sisa stok vaksin yang masih tersedia dan merencanakan tindak lanjut untuk pemberian vaksinasi COVID-19 Dosis 2.

Tabel 1. Prosedur Kegiatan

\begin{tabular}{|c|c|c|}
\hline No & Kegiatan & Prosedur \\
\hline \multirow[t]{3}{*}{1} & Perencanaan & 1. Pembagian tugas \\
\hline & & 2. Penentuan lokasi dan waktu \\
\hline & & 3. Penentuan sasaran vaksinasi \\
\hline \multirow[t]{10}{*}{2} & Pelaksanaan & $\begin{array}{l}\text { 1. Pemberdayaan masyarakat dengan mengajak } \\
\text { ke lokasi vaksinasi }\end{array}$ \\
\hline & & $\begin{array}{l}\text { 2. Memberikan penyuluhan, informasi dan } \\
\text { sosialisasi kepada masyarakat }\end{array}$ \\
\hline & & $\begin{array}{l}\text { 3. Tim vaksinasi memberikan pelayanan } \\
\text { vaksinasi kepada } \\
\text { sebagai berikut: }\end{array}$ \\
\hline & & $\begin{array}{l}\text { a. Dating dengan menggunakan masker, } \\
\text { mencuci tangan di lokasi }\end{array}$ \\
\hline & & b. Mengisi daftar hadir \\
\hline & & c. Mengklarifikasi data sasaran \\
\hline & & d. Melakukan screening riwayat kesehatan \\
\hline & & e. Memberikan suntik vaksin COVID-19 \\
\hline & & $\begin{array}{l}\text { f. Mengentri data dan mencetak sertifikat } \\
\text { untuk diserahkan kepada peserta }\end{array}$ \\
\hline & & $\begin{array}{l}\text { g. Memantau kondisi kesehatan pasca } \\
\text { penyuntikan vaksinasi kurang lebih } 30 \\
\text { menit }\end{array}$ \\
\hline \multirow[t]{4}{*}{3} & Evaluasi & 1. Menganalisis jumlah peserta yang divaksinasi \\
\hline & & $\begin{array}{l}\text { 2. Menganalisis kasus kejadian Ikutan Pasca } \\
\text { Imunisasi bila ada }\end{array}$ \\
\hline & & $\begin{array}{l}\text { 3. Menganalisis sisa stok vaksin yang masih } \\
\text { tersedia }\end{array}$ \\
\hline & & $\begin{array}{l}\text { 4. Merencanakan tindak lanjut untuk pemberian } \\
\text { vaksinasi dosis } 2\end{array}$ \\
\hline
\end{tabular}

\section{HASIL DAN PEMBAHASAN}

\subsection{COVID-19}

Akhir tahun 2020, Indonesia dihadapkan dengan kasus kesehatan yang cukup meresahkan. Masyarakat dikhawatirkan dengan sebuah penyakit yang disebabkan oleh Coronavirus Disease (COVID-19). Penyakit ini memiliki intensitas penularan sangat cepat dan meluas, menyerang sistem pernafasan seseorang, dan tidak sedikit telah menelan korban jiwa (Kemenkes, 2020). World Health Organization (WHO) menetapkan COVID-19 sebagai Public Health Emergency of International Concern (PHEIC) atau Kegawatdaruratan Kesehatan Masyarakat yang Meresahkan Dunia (KKMMD) dan sampai pada tanggal tanggal 11 Maret 2020, WHO pun menetapkan penyakit ini sebagai pandemi (Novita1 \& Ramadhani, 2021).

Besarnya penyebaran COVID-19 secara global dan adanya deklarasi oleh WHO sebagai pandemi darurat kesehatan masyarakat, maka timbul kebutuhan mendesak akan diagnosa yang 
cepat, vaksin, dan terapi COVID-19 (Puspasari \& Achadi, 2021). Vaksinasi telah dilakukan oleh berbagai negara, termasuk Indonesia, untuk pencegahan infeksi SARS-CoV-2. Sesuai dengan Surat Keputusan Menteri Kesehatan Nomor HK.01.07/MENKES/9860/2020 tentang penetapan jenis vaksin untuk pelaksanaan vaksinasi COVID-19, terdapat 6 (enam) jenis vaksin yang akan digunakan di Indonesia, diantaranya adalah Vaksin Merah Putih, AstraZeneca, China National Pharmaceutical Group Corporation (Sinopharm), Moderna, Pfizer Inc and BioNTech, dan Sinovac Biotech Ltd. Hasil evaluasi menunjukkan vaksin Coronavac yang diproduksi oleh Sinovac Biotech yang juga didaftarkan di Indonesia oleh PT. Bio Farma aman untuk digunakan, dengan kejadian efek samping yang ditimbulkan bersifat ringan hingga sedang, namun efek samping tersebut bukan merupakan efek samping yang berbahaya dan dapat pulih kembali (Novita1 \& Ramadhani, 2021).

\subsection{Sosialisasi dan Pemberian Vaksinasi}

Edukasi lanjutan dilakukan sebagai perwakilan perguruan tinggi menjelaskan bahwa tantangan informasi vaksin tidak valid (Hoax) membuat keraguan masyarakat untuk divaksin (vaccine hesitancy). Vaccine Hesitancy adalah menunda atau menolah untuk di vaksin, karena ragu sehingga lebih $90 \%$ negara di dunia masyarakat terdapat vaccine hesitancy. Upaya komunikasi, informasi, dan edukasi (KIE) lebih massif. Perlu adanya manajemen isu dengan menyaring berbagai informasi di masyarakat terutama mitra dengan kelompok masyarakat yang potensial (Novita1 \& Ramadhani, 2021).

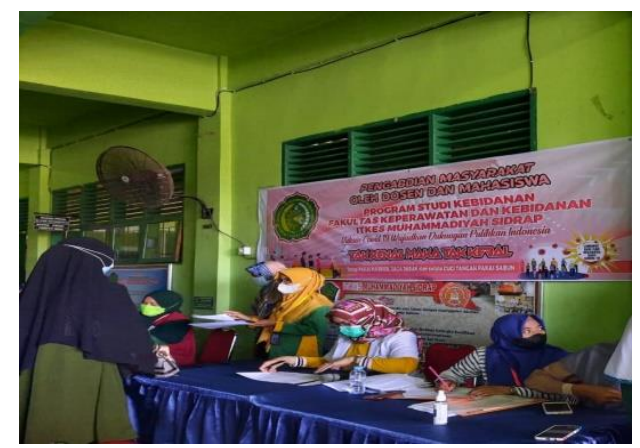

Gambar 1. Sosialisasi sebelum dilakukan vaksinasi

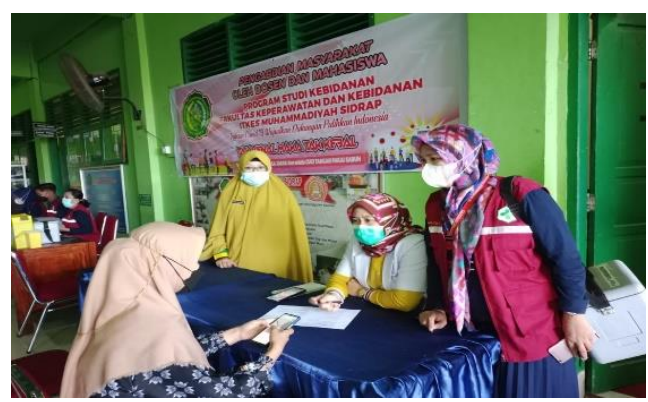

Gambar 2. Screening riwayat kesehatan

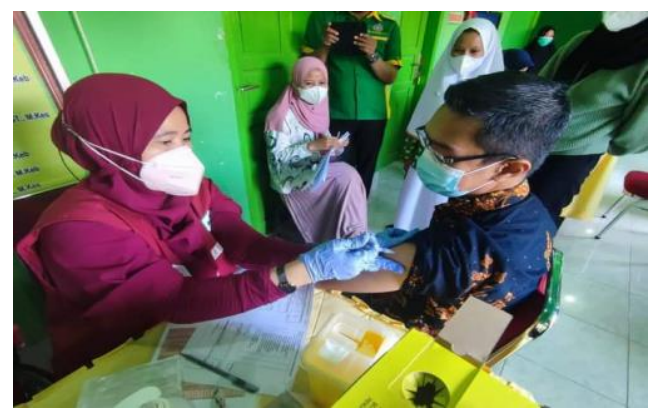

Gambar 3. Pemberian Vaksinasi COVID-19 


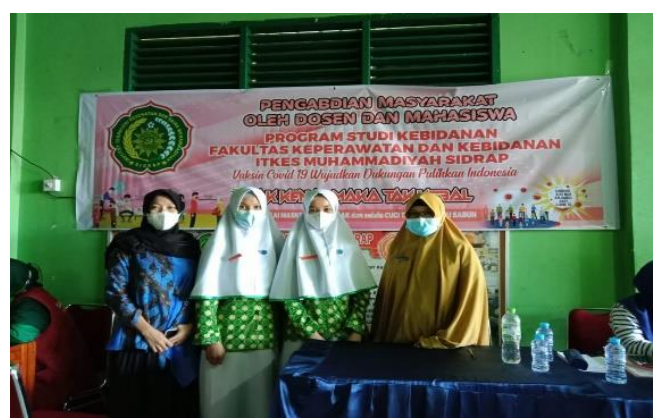

Gambar 4. Foto bersama dengan beberapa unsur yang terlibat

Pengabdian masyarakat dilakukan sosialisasi dan pemberian vaksinasi COVID-19 bagi masyarakat pada hari Kamis tanggal 09 September 2021 jam 08.00 sampai jam 15.00 wita di ITKES Muhammadiyah Sidrap telah berhasil memberikan vaksinasi pada 400 orang. Kegiatan pemberian vaksin COVID-19 kepada masyarakat ini bertujuan untuk meningkatkan imunitas tubuh dengan mengaktifkan antibodi dalam tubuh supaya dapat mengurangi dampak dari penularan Penyakit COVID-19 dan sebagai upaya memutus penyebaran penyakit COVID-19. Tujuan dari pemberian vaksinasi COVID-19 ini tidak lepas dari Teori Tingkatan Penanggulangan Penyakit. Pencegahan penyakit merupakan suatu bentuk upaya kegiatan pelayanan kesehatan berupa pencegahan, penanganan dan rehabilitasi yang terdiri dari peningkatan kesehatan (health promotion), perlindungan umum dan khusus terhadap penyakit-penyakit tertentu (general and specific protection), penegakan diagnose secara dini dan pengobatan yang cepat dan tepat (early diagnosis and prompt treatment), pembatasan kecacatan (disability limitation) dan pemulihan kesehatan (rehabilitation).

Hasil dari kegiatan pengabdian masyarakat ini melalui pemberian vaksinasi COVID-19 kepada masyarakat menghasilkan suatu pemahaman dan perubahan perilaku dari masyarakat tentang pencegahan penyakit COVID-19 dalam upaya untuk mencegah rantai penyebaran penyakit COVID-19. Masyarakat sangat antusias serta semangat untuk mendapatkan vaksinasi setelah dilakukan sosialisasi tentang vaksinasi dilihat dari jumlah peserta vaksin 400 orang. Pihak mitra sendiri merasa puas dan merasa terbantu melalui kegiatan ini, dimana memudahkan mereka dalam memenuhi capaian vaksinasi COVID-19 dan dapat membantu memutus rantai penularan Penyakit COVID-19.

\section{KESIMPULAN}

Kegiatan Pengabdian masyarakat melalui sosialisasi dan pemberian vaksinasi COVID-19 di ITKES Muhammadiyah Sidrap merupakan upaya pencegahan penyakit COVID-19 dalam memutus penyebaran penyakit COVID-19. Kegiatan ini sebagai dukungan upaya kebijakan pemerintah dalam mengurangi resiko penularan penyakit COVID-19. Banyak kekurangan dalam pelaksanaan kegiatan ini karena waktu persiapan yang pendek dengan keterbatasan tenaga pelaksana. Harapan penulis pengabdian masyarakat ini dapat berefek lebih luas seperti memberikan vaksinasi kepada kelompok sasaran masyarakat yang lain, usia lanjut dan seluruh lapisan masyarakat sehingga mencegah penularan penyakit COVID-19. Selain itu, pemberian vaksinasi diharapkan tidak hanya melibatkan fasilitas kesehatan milik pemerintah saja tetapi juga melibatkan sektor fasilitas kesehatan swasta serta perguruan tinggi di semua titik lokasi.

\section{UCAPAN TERIMA KASIH}

Terima kasih sebesar-besarnya kepada segala pihak yang terlibat dan telah memberikan bantuan, arahan, bimbingan sehingga kegiatan ini dapat diselesaikan dengan baik 


\section{DAFTAR PUSTAKA}

Dewi, A., \& Bustan, R. (2021). Sosialisasi Vaksinasi COVID-19 dan Protokol Kesehatan 7M Sebagai Upaya Pencegahan Penyebaran Virus COVID-19. Seminar Nasional Penelitian dan Pengabdian kepada Masyarakat (SNPPM-3), 197-209.

Hartini, S., Nuraeni, N., Hayuningtyas, R. Y., \& Serli, R. K. (2020). Aksi Peduli COVID-19 Berupa Sosialisasi dan Gerakan Kepedulian STMIK Nusa Mandiri Bersama Lawan COVID-19. Jurnal Pengabdian Kepada Masyarakat Nusa Mandiri, 1-6.

Indiani, N. M. (2021). Flexibilitas Pembelajaran Jarak Jauh Sebagai Adaptasi Merdeka Belajar Kampus Merdeka. Seminar Nasional (pp. 37-48). Denpasar: UNHI PRESS.

Indrawati, B. (2020). Tantangan Dan Peluang Pendidikan Tinggi Dalam Masa Dan Pasca Pandemi COVID-19. Jurnal Kajian Ilmiah (JKI), 39 - 48.

Novianto, A. S., Masrukhan, A. Q., Zakariya, I., Iksan, Muhamad, A., Wardani, N. L., et al. (2021). Edukasi Masyarakat Melalui Program Sosialisasi Vaksinasi di Masa Pandemi COVID-19. Jurnal Pemberdayaan Pembelajaran Masyarakat (JP2M), 137-141.

Novita1, A., \& Ramadhani, N. R. (2021). Webinar Vaksinasi COVID-19 Untuk Meningkatkan Kesadaran Masyarakat. Shihatuna: Jurnal Pengabdian Kesehatan Masyarakat, 29-33.

Nurdiana, A., Marlina, R., \& Adityasning, W. (2021). Berantas Hoax Seputar Vaksin COVID-19 Melalui Kegiatan Edukasi dan Sosialisasi Vaksin COVID-19. Abdimas Umtas: Jurnal Pengabdian Kepada Masyarakat, 489-495.

Puspasari, A., \& Achadi, A. (2021). Pendekatan Health Belief Model untuk Menganalisis Penerimaan COVID-19 di Indonesia. urnal Ilmiah Indonesia.

Rachmadi, T., Rahayu, T. P., Waluyo, A., \& Yuliyanto, W. (2021). Pemberian Vaksinasi COVID-19 Bagi Masyarakat Kelompok Petugas Pelayanan Publik di Kecamatan Buluspesantren. Jurnal Pengabdian Kepada Masyarakat, 318-333. 